\title{
Kajian Penggunaan Ciprofloxacin terhadap Hematologi Ikan Botia (Botia macracanthus, Bleeker) yang Diinfeksi Bakteri Aeromonas hydrophila
}

\author{
Maftuch ${ }^{1}$, Happy Nursyam ${ }^{1 *}$, Sukarni $^{2}$ \\ ${ }^{1}$ Fakultas Perikanan dan Ilmu Kelautan, Universitas Brawijaya \\ ${ }^{1}$ Stasiun Karantina Ikan Sulthan Thaha Jambi
}

\begin{abstract}
Abstrak
Uji hematologi sangat bermanfaat sebagai alat diagnostik didalam menetapkan status kesehatan ikan. Salah satu aspek dari infeksi adalah terjadinya perubahan gambaran darah. Pemeriksaan darah dapat digunakan sebagai indikator keparahan suatu penyakit tertentu. Beberapa parameter yang dapat memperlihatkan perubahan patologi pada darah meliputi jumlah leukosit, deferensial leukosit, eritrosit. Dari hasil penelitian diketahui jumlah rata-rata sel darah merah dalam darah ikan botia sehat pada masingmasing perlakuan K-, K+, A, B, C, D berturut-turut adalah 2.470.000, 2.500.000, 2.560.000, 2.350.000, 2.440.000, dan 2.430.000. Sementara itu pada ikan botia yang terinfeksi bakteri A.hydrophila diketahui jumlah rata-rata eritrosit pada masing-masing perlakuan $\mathrm{K}-, \mathrm{K}+, \mathrm{A}, \mathrm{B}, \mathrm{C}$, dan $\mathrm{D}$ berturut-turut adalah $2.420 .0000,1.770 .000,1.780 .000,1.890 .000,1.780 .000$, dan 1.870.000. jumlah rata-rata eritrosit ikan botia yang terinfeksi bakteri A.hydrophila, dan kemudian diobati dengan ciprofloxacin pada masing-masing perlakuan K-, K+,A, B, C, dan D berturut-turut adalah 2.420.000, 1.630.000, 2.090.000, 2.280.000, 2.500.000, dah 2.540.000. Sementara jumlah rata-rata sel darah putih dalam darah ikan botia yang sehat pada masingmasing perlakuan K-, K+, A, B, C, D berturut-turut adalah 97.000, 90.000, 88.000, 87.000, 93.000 dan 88.000. Sementara itu jumlah rata-rata sel darah putih pada ikan botia yang terinfeksi bakteri A.hydrophila, pada masing-masing perlakuan $\mathrm{K}_{-}, \mathrm{K}+, \mathrm{A}, \mathrm{B}, \mathrm{C}$, D berturut-turut adalah 97.000, 174.000, 174.000, 179.000, 185.000 dan 185.000. Sedangkan dari hasil penelitian terhadap ikan botia yang terinfeksi A.hydrophila dan kemudian diobati dengan ciprofloxacin diperoleh hasil perhitungan rata-rata leukosit pada masing-masing perlakuan berturut-turut adalah sebagai berikut 980.000, 189.000, 125.000, 137.000, 133.000, dan 136.000 .
\end{abstract}

Kata Kunci : Aeromonas hydrophila, eritrosit, hemotologi, ikan botia, leukosit

\section{Abstract}

Hematology test is very useful as a diagnostic tool in determining the fish health status. An aspect of the infection is the change in blood figure. Blood tests can be used as an indicator of severity on a particular disease. Some parameters that show pathological changes in the blood include the number of leukocytes, deferential of leukocytes, and erythrocytes. The results showed the average number of red blood cells in the blood of healthy Botia fish in each treatment of $K_{-}, \mathrm{K}+, \mathrm{A}, \mathrm{B}, \mathrm{C}, \mathrm{D}$ are 2.470.000, 2.500.000, 2.560.000, 2.350.000, 2.440.000, and 2.430.000, respectively. Otherwise, in the A. Hydrophila-infected botia has the average number of erythrocytes in each treatment of $K_{-}, \mathrm{K}+, \mathrm{A}, \mathrm{B}, \mathrm{C}$, and $\mathrm{D}$ are 2.420.0000, 1.770.000, $1.780 .000,1.890 .000,1.780 .000$, and 1.870 .000 , respectively. The average number of erythrocytes in $A$. Hydrophila-infected botia which treated by ciprofloxacin in each treatment of $\mathrm{K}_{-}, \mathrm{K}+, \mathrm{A}, \mathrm{B}, \mathrm{C}$, and D are $2.420 .000,1.630 .000,2.090 .000,2.280 .000,2.500 .000$, and 2.540.000, respectively. Otherwise, the average number of leukocytes in health botia in each treatment of $\mathrm{K}_{-}, \mathrm{K}+, \mathrm{A}, \mathrm{B}, \mathrm{C}, \mathrm{D}$ are 97.000, 90.000, 88.000, $87.000,93.000$ and 88.000, respectively. Whereas, the average number of leukocytes in $A$. Hydrophilainfected botia in each treatment of $\mathrm{K}-, \mathrm{K}+, \mathrm{A}, \mathrm{B}, \mathrm{C}, \mathrm{D}$ are 97.000,174.000,174.000,179.000, 185.000 and 185.000 , respectively. The result also show that $A$. Hydrophila-infected botia which treated by ciprofloxacin has the average number of leukocytes in each treatment respectively are 980.000, 189.000, 125.000, $137.000,133.000$, and 136.000 .

Keywords : Aeromonas hydrophila, erythrocyte, hemotology, botia fish, leukocytes 


\section{PENDAHULUAN}

Penyakit bakterial pada ikan merupakan salah satu penyakit yang dapat menimbulkan kerugian yang tidak sedikit. Selain dapat mematikan ikan, penyakit yang disebabkan oleh bakteri juga dapat menurunkan kualitas daging ikan yang terinfeksi. Penyakit akibat bakteri di Indonesia ternyata dapat mengakibatkan kematian sekitar 50$100 \%$ Hematologi sangat erat kaitannya dengan patologi, terutama untuk memperoleh gambaran ikan tersebut dalam keadaan sehat atau sakit. [1]. Darah terdiri dari dua kelompok besar yaitu sel dan plasma. Adapun sel darah terdiri dari sel darah merah (eritrosit) dan sel darah putih (leukosit). Berdasarkan warnanya sel darah dibagi menjadi sel darah merah dan sel darah putih. Darah mengandung sel-sel yang dirancang untuk mencegah infeksi, menghentikan pendarahan dan mengangkut hormon. Sel darah mempunyai peranan sangat penting dalam system kekebalan, terutama leukosit atau sel darah putih. Jenis-jenis leukosit mempunyai beberapa fungsi dalam melawan benda asing yang berhasil masuk kedalam tubuh [1]. Pada ikan yang normal, jumlah sel darah merah berkisar antara 1.050.000-3.000.000 sel $/ \mathrm{mm}^{3}$ darah [2].

Pada ikan yang normal, jumlah sel darah merah berkisar antara 1.050.000- 3.000.000 $\mathrm{sel} / \mathrm{mm}^{3}$ darah [2]. Rendahnya jumlah sel darah merah (eritrosit) menandakan ikan dalam keadaan stress [3]. Apabila jumlah eritrosit berkurang maka keadaan tersebut ada indikasi masuknya benda asing ke dalam tubuh. menyatakan bahwa eritrosit ikan mempunyai inti dengan sel lonjong, berwarna merah kekuningan dan berukuran $12-13 \mu \mathrm{m}$ dengan diameter $4-5$ $\mu \mathrm{m}$.

Leukosit memiliki bentuk khas, nukleus, sitoplasma dan organel, semuanya bersifat mampu bergerak pada keadaan tertentu. Eritrosit bersifat pasif dan melaksanakan fungsinya dalam pembuluh darah, sedangkan leukosit mampu keluar dari pembuluh darah menuju jaringan dalam menjalankan fungsinya. Jumlah seluruh leukosit jauh di bawah eritrosit, dan bervariasi tergantung jenis hewannya. Fluktuasi dalam jumlah leukosit pada tiap individu cukup besar pada kondisi tertentu, misalnya: stress, aktivitas fisiologis, gizi, umur,

\footnotetext{
* Alamat korespondensi:

Happy Nursyam

Email : happy_nsy@ub.ac.id

Alamat : Fakultas Perikanan dan Ilmu Kelautan Universitas Brawijaya
}

dan lain-lain. Jumlah leukosit yang menyimpang dari keadaan normal mempunyai arti klinik penting untuk evaluasi proses penyakit. Setelah dibentuk sel-sel ini diangkut dalam darah menuju berbagai bagian tubuh untuk digunakan Kebanyakan sel darah putih ditranspor secara khusus ke daerah yang terinfeksi dan mengalami peradangan serius [4]. Jumlah sel darah putih pada ikan berkisar antara 20.000-150.000 $\mathrm{sel} / \mathrm{mm}^{3}$ darah [5].

Penelitian ini bertujuan untuk Mengetahui gambaran hematology pada eritrosit, leukosit dan deferensial leukosit ikan sehat, ikan saat terinfeksi dan ikan sesudah pengobatan. Analisa hasil penelitian dengan menggunakan uji statistik sesuai dengan pola percobaan adalah RAL dan tiap perlakuan diulang 3 kali. Selanjutnya dilakukan analisa keragaman dengan uji $F$ (ANOVA) dengan program SPSS 18 oneway, yaitu meliputi Descriptives, Test of homogeneity, ANOVA, Post Hoct Tests (Interpolasi), hasil akhir dianalisa pada Homogeneous subsets, dan Paired T-Test. Hal ini untuk membuktikan adanya Beda nyata, atau tidak terhadap perlakuan.

\section{METODE PENELITIAN \\ Pengambilan sample darah}

Darah ikan diambil pada bagian depan sirip ekor, sirip punggung, menggunakan spuit suntik yang terlebih dahulu diberi anti koagulan dengan $\mathrm{Na}$ Citrate atau $\mathrm{Na}_{2}$ EDTA sebanyak 0,1 ml, jarum suntik dibuat dengan kemiringan $45^{\circ}$. Darah yang diambil dimasukan dalam tube dan langsung disimpan pada refrigator.

\section{Perhitungan jumlah leukosit}

Darah diencerkan dalam pipet leukosit, kemudian dimasukkan ke dalam kamar hitung. Jumlah leukosit dihitung dengan volume tertentu dengan mengenakan faktor konversi jumlah leukosit per $\mu \mathrm{l}$ darah dapat. Larutan TURK digunakan sebagai larutan pengencer dengan komposisi larutan gentianviolet $1 \%$ dalam air 1 $\mathrm{ml}$, asam asetat glasial $1 \mathrm{ml}$, aquadest ad $100 \mathrm{ml}$. Disaring sebelum dipakai.

\section{Penghitungan Jumlah Eritrosit}

Darah diencerkan dalam pipet eritrosit, kemudian dimasukkan kedalam kamar hitung. Jumlah eritrosit dihitung dalam volume tertentu dengan menggunakan faktor konversi, jumlah eritrosit per $\mu \mathrm{l}$ darah. Larutan pengencer yang dipakai adalah larutan HAYEM, dengan komposisi natrium sulfat (berair kristal) 5 g; natrium klorida $1 \mathrm{~g}$; merkuri klorida $0,5 \mathrm{~g}$, aquadest ad $200 \mathrm{ml}$. 
Juga dapat dipakai larutan GOWERS : natrium sulfat $12,5 \mathrm{~g}$; asam asetat glasial $33,3 \mathrm{ml}$; aquadest ad $200 \mathrm{ml}$. Disaring sebelum dipakai.

\section{HASIL DAN PEMBAHASAN \\ Eritrosit}

Jumlah rata-rata sel darah merah dalam darah ikan botia sehat pada masing-masing perlakuan $\mathrm{K}-, \mathrm{K}+, \mathrm{A}, \mathrm{B}, \mathrm{C}$, D berturut-turut adalah $2.470 .000,2.500 .000,2.560 .000,2.350 .000$, 2.440.000, dan 2.430.000. Kondisi ini masing normal dikarenakan ikan tidak memperoleh stressing dan didukung dengan kondisi lingkungan yang kondusif untuk kehidupan ikan botia.

Sementara itu pada ikan botia yang terinfeksi bakteri A.hydrophila diketahui jumlah rata-rata eritrosit pada masing-masing perlakuan $\mathrm{K}-, \mathrm{K}+, \mathrm{A}$, B, C, dan D berturut-turut adalah 2.420.0000, $1.770 .000,1.780 .000,1.890 .000,1.780 .000$, dan 1.870.000. Dari hasil perhitungan pada jumlah eritrosit ikan botia yang terinfeksi bakteri A.hydrophila mengalami penurunan yang drastis dibandingkan dengan jumlah eritrosit pada ikan botia yang sehat, hal ini dikarenakan adanya diduga diakibatkan adanya kontak dengan bakteri. Kontak tersebut mengakibatkan organ insang mengalami iritasi dan mengeluarkan mucus (lendir) sebagai perlindungan terhadap serangan bakteri. Akan tetapi mukus yang dihasilkan justru menutup permukaan lamella insang sehingga pertukaran $\mathrm{O}_{2}$ dengan $\mathrm{CO}_{2}$ terhambat, akibatnya tidak ada pengikatan oksigen oleh hemoglobin darah. Hal ini menyebabkan transportasi oksigen ke seluruh tubuh tidak ada, akibatnya ikan akan mengalami hypoksia (kekurangan oksigen).

Dari hasil penelitian terhadap jumlah ratarata eritrosit ikan botia yang terinfeksi bakteri A.hydrophila, dan kemudian diobati dengan ciprofloxacin pada masing-masing perlakuan K-, $\mathrm{K}+, \mathrm{A}, \mathrm{B}, \mathrm{C}$, dan $\mathrm{D}$ berturut-turut adalah $2.420 .000,1.630 .000,2.090 .000,2.280 .000$, 2.500.000, dah 2.540.000. Jumlah eritrosit ikan botia yang diobati dengan ciprofloxacin cenderung naik dibandingkan dengan jumlah eritrosit ikan botia yang terinfeksi, dan jumlahnya mendekati normal. Kontrol positif $(\mathrm{K}+)$, yaitu ikan botia yang terinfeksi A.hydropila dan tidak diobati, jumlah eritrosit justru semakin menurun jumlahnya. Jumlah eritrosit pada kondisi sehat adalah 2.500.000, kondisi terinfeksi 1.770.000, dan kondisi ikan terinfeksi tanpa diobati adalah 1.630.000. hal ini disebabkan kondisi insang semakin buruk, dan infeksi bakteri juga semakin parah, sehingga menyebabkan kerja insang terganggu, yang berimbas pada kesulitan $\mathrm{Hb}$ mengikat oksigen. Berkurangnya jumlah eritrosit juga diduga disebabkan karena terjadinya anemia pada ikan. Anemia berdampak pada terhambatnya pertumbuhan ikan, karena rendahnya jumlah eritrosit mengakibatkan suplai makanan ke sel, jaringan dan organ akan berkurang sehingga proses metabolisme ikan akan terhambat.

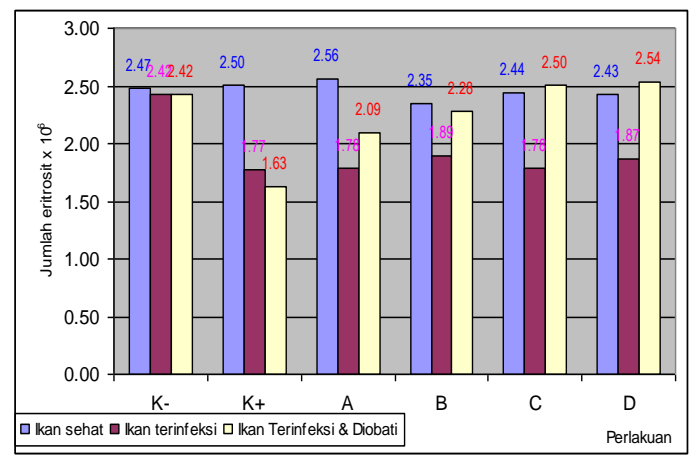

Gambar 1. Jumlah Rata-rata Eritrosit

Dari hasil uji Paired Samples T-Test diketahui bahwa jumlah eritrosit ikan botia sehat berbeda nyata dengan jumlah eritrosit ikan botia yang terinfeksi, ini dibuktikan dengan hasil probabilitas Pair 1 lebih kecil dibandingkan dengan $\alpha$, yaitu $0.00<0.005$. Sedangkan untuk Pair 2 yaitu perbandingan jumlah eritrosit ikan botia sehat dengan jumlah eritrosit ikan botia diobati adalah tidak berbeda nyata, ini dibuktikan dengan hasil probabilitasnya lebih besar dibandingkan dengan $\alpha$, yaitu $0.030>0.005$. Dan hasil dari Pair 3 yaitu perbandingan jumlah eritrosit ikan botia diobati dengan jumlah eritrosit ikan botia sakit adalah berbeda nyata, hal ini terlihat pada hasil probabilitasnya lebih kecil dibandingkan dengan $\alpha$, yaitu $0.001<0.005$.

\section{Leukosit (Sel Darah Putih)}

Jumlah rata-rata sel darah putih dalam darah ikan botia yang sehat pada masing-masing perlakuan $\mathrm{K}-, \mathrm{K}+, \mathrm{A}, \mathrm{B}, \mathrm{C}$, D berturut-turut adalah 97.000, 90.000, 88.000, 87.000, 93.000 dan 88.000. Jumlah leukosit pada ikan botia sehat berada dalam kisaran normal. Hal ini dikarekan kondisi lingkungan yang mendukung hidup ikan, yaitu tidak adanya stressing dan kualitas air yang layak. Jumlah seluruh leukosit jauh di bawah eritrosit, dan bervariasi tergantung jenis hewannya. Fluktuasi dalam jumlah leukosit pada tiap individu cukup besar pada kondisi tertentu, misalnya: stress, aktivitas fisiologis, gizi, umur, dan lain-lain. Jumlah leukosit yang menyimpang 
dari keadaan normal mempunyai arti klinik penting untuk evaluasi proses penyakit, itu jumlah rata-rata sel darah putih pada ikan botia yang terinfeksi bakteri A.hydrophila, pada masing-masing perlakuan K-, K+, A, B, C, D berturut-turut adalah 97.000, 174.000, 174.000, $179.000,185.000$ dan 185.000. Jumlah leukosit pada ikan botia yang terinfeksi jumlahnya cenderung naik dengan drastis. Hal ini diduga karena ikan dalam kondisi stress akibat adanya infeksi bakteri A.hydrophila pada darah ikan dan organ lainnya. Jumlah leukosit pada ikan kontrol cenderung normal jika dibandingkan dengan ikan perlakuan. Hal ini menunjukkan bahwa ikan kontrol tidak dalam keadaan stress atau hidup pada lingkungan yang normal. Sedangkan pada ikan perlakuan, jumlah leukosit terus meningkat, ini disebabkan karena ikan perlakuan berusaha mempertahankan diri dari kondisi buruk akibat pemaparan bakteri yang dapat dilihat dari jumlah sel darah putih yang terus meningkat serta tubuh ikan tersebut akan membentuk antibodi. Leukosit merupakan sel yang berperan penting dalam sistem pertahanan seluler tubuh, sehingga peningkatan leukosit merupakan reaksi untuk meningkatkan daya tahan ikan uji. Selain itu naiknya jumlah leukosit ikan botia yang terinfeksi diduga juga karena sifat leukosit yang bersifat aktif atau mobile, yaitu leukosit akan bergerak menuju pada organ yang terinfeksi atau mengalami gangguan.

Sedangkan dari hasil penelitian terhadap ikan botia yang terinfeksi $A$.hydrophila dan kemudian diobati dengan ciprofloxacin diperoleh hasil perhitungan rata-rata leukosit pada masingmasing perlakuan berturut-turut adalah sebagai berikut 980.000, 189.000, 125.000, 137.000, 133.000, dan 136.000. Jumlah rata-rata leukosit pada ikan yang diobati dengan ciprofloxacin terlihat menurun, hal ini disebabkan adanya aktifitas ciprofloxacin yang membuat bakteri mati, sehingga infeksi berhenti, dan ikan tidak dalam kondisi stress. Karena infeksi berhenti maka keberadaan leukosit sebagai fagositor tidak diperlukan lagi, dengan demikian jumlah leukosit kembali mendekati jumlah normal.

Berbeda dengan jumlah leukosit pada ikan botia yang terinfeksi tetapi tidak diobati dengan antibiotik, jumlahnya terus meningkat sampai akhir penelitian, hal ini disebabkan ikan berusaha meningkatkan daya tahan tubuhnya dari serangan bakteri, sehingga leukosit bergerak aktif menuju daerah yang terkena infeksi.Selain itu ikan juga dalam keadaan stress yang mengakibatkan metabolisme ikan terganggu, sehingga pembentukan energi juga teranggu, hal inilah yang membuat ikan terlihat lemah dan tidak mau berenang.

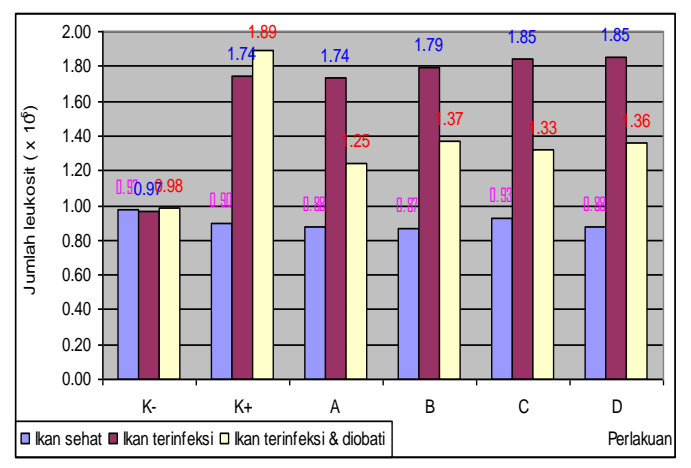

Gambar 3. Jumlah Rerata Leukosit Ikan Botia

Dari hasil uji Paired Samples T-Test diketahui bahwa jumlah leukosit ikan botia sehat berbeda nyata dengan jumlah leukosit ikan botia yang terinfeksi, ini dibuktikan dengan hasil probabilitas Pair 1 lebih kecil dibandingkan dengan $\alpha$, yaitu $0.00<0.005$. Sedangkan untuk Pair 2 yaitu perbandingan jumlah leukosit ikan botia sehat dengan jumlah leukosit ikan botia diobati adalah berbeda nyata, ini dibuktikan dengan hasil probabilitasnya lebih kecil dibandingkan dengan $\alpha$, yaitu $0.000<0.005$. Dan hasil dari Pair 3 yaitu perbandingan jumlah leukosit ikan botia diobati dengan jumlah leukosit ikan botia sakit adalah berbeda nyata, hal ini terlihat pada hasil probabilitasnya lebih kecil dibandingkan dengan $\alpha$, yaitu $0.000<0.005$.

\section{KESIMPULAN}

Dari hasil penelitian dapat disimpulkan bahwa pemberian ciprofloxacin mampu mengendalikan infeksi bakteri A.hydrophila pada ikan botia, terlihat dari penurunan jumlah leukosit dan meningkatnya kembali jumlah eritrosit.

\section{SARAN}

Berdasarkan penelitian maka disarankan untuk dilakukan penelitian lebih lanjut mengenai gambaran hematology lainnya, seperti $\mathrm{Hb}$, hematokit, makrofag dan lainnya. Dan perlu dilakukan pengujian terhadap antibiotiik lainnya sehingga diperoleh antibiotic yang benar-benar efektif untuk mengendalikan A.hydrophila yang menyerang ikan botia.

\section{DAFTAR PUSTAKA}

[1] Johny F., Zafran, Roza D. dan Ketut M. 2003. Hematologi beberapa spesies ikan laut 
budidaya. Jurnal Penelitian Perikanan Indonesia. 9 (4): 63-41.

[2] Roberts R.J. 1978. Fish pathology. A Bailliere Tindall Book, Publ. Cassell Ltd.

[3] Wedemeyer G.A. dan Yasutake W.T. 1977. Clinical methods for the assessment of the effects of environmental stress on fish health. US Dept. Interior Fish Wildl. Ser. Tech. Pap. 89: 18p.

[4] Adair T.H. dan Guyton A.C. 1983. Modification of lymp by lymph nodes. II. Effect of increased lymph node venous blood pressure. Am. J. Physiol. 245 (4): H616-622.

[5] Rastogi R.K., Saxena P.K. dan lela L. 1977. Hydroxysteroid dehydrogenase activity in the ovary of Lacerta sicula Raf. during the annual cycle. Monit. Zool. Ital. (N.S.). 11: 33-46. 